\title{
Lobbyists prompt US breast cancer campaign
}

Washington. Inspired by the success of the grass-roots AIDS lobby, interest groups representing breast-cancer sufferers have persuaded the Clinton administration to launch a national strategy to combat the disease, ranging from fundamental research to enhanced screening programmes.

Breast cancer strikes one out of every nine American women. More than 180,000 cases are diagnosed in the United States and about 46,000 people will die from the disease each year.

About two hundred experts and leaders representing all interests within the breastcancer community met at the US National Institutes of Health (NIH) this week to thrash out the details of a national plan of action.

The NIH conference brought together high-ranking public officials from the Clinton administration, including the Health Secretary Donna Shalala and the Surgeon General Joycelyn Elders, as well as members of congress, senior NIH officials, researchers and representatives of patient advocacy and support groups.

Ruth L. Kirschstein, deputy director of $\mathrm{NIH}$, says that the aim of the conference was to bring together people with "many diverse points of view, needs and interests". Rather than representing any one interest group, she says participants were expected to speak for "the population of the United States, as this is a concern that men as well as women should have".

Participants, divided into smaller groups, were asked to identify issues and goals of national priority in six broad areas, ranging from consumer education to "the translation of research into practice",

President Bill Clinton promised to convene a special conference to develop a national strategy to fight the disease after a meeting with leaders of the National Breast Cancer Coalition (NBCC) during their march on Washington DC in October.

Organizations such as the NBCC are taking their lead from the AIDS lobby, which has become a powerful political force built largely on grass-roots efforts. The strategy seems to paying off: the National Cancer Institute will spend an estimated US $\$ 263$ million on breast cancer research in the fiscal year 1994 (which started on 1 October), an increase of 34 per cent over 1993.

October was also the month when the President's Cancer Panel special commission on breast cancer delivered a 26-page report in which it said that high priority should be given to research on the causes of breast cancer and prevention, to newer

imaging techniques and to the continued development of more specific, less invasive and less toxic methods of treatment.

The commission also emphasized the need to promote the use of screening mammography and clinical breast examinations among older women, women from rural areas, women of lower socioeconomic status and women of certain racial and ethnic populations who, typically, are under-represented. To achieve these goals, the commission recommended that the federal government should spend "no less than US $\$ 500$ million" annually on breast cancer research.

Nancy G. Brinker, chairman of the special commission, and founding chairman of the Susan G. Komen Breast Cancer Foundation in Dallas, Texas, says she hopes the commission's report will serve as the centrepiece for the strategic plan. "To re-invent this process would be a serious waste of money and effort", she says.

Diane Gershon

\section{Rival Boston hospitals set to merge}

Washington. Two of the United States' most medically sophisticated and fiercely competitive hospitals have announced that they are to merge. The merger is designed to meet the challenge of health care reform that is being driven by an unrelenting determination to cut the cost of medical care (see Nature 366, 200-202; 1993).

The Massachusetts General Hospital (MGH) and the Brigham and Women's Hospital, two Harvard-affiliated teaching

\section{High bids for second-hand space suits}

\begin{abstract}
Last weekend, as the Russian people voted 'yes' to President Boris Yeltsin, his free market democracy was in evidence at Sotheby's in New York when more than 200 artefacts from the Soviet space programme went under the auctioneer's hammer.
\end{abstract}

Alexel Leonov, the first man to walk in space, watched his training space suit (see right) fetch $\mathbf{\$ 2 5 5 , 5 0 0}$. But it was not only hard cash that motivated the sale. "It permits an exchange of cultural values," sald Leonov.

Western museums and historians saw the sale as a chance to set the record straight. "If you look at museums of science and technology around the world, there's a lot of NASA material. There's virtually nothing from the Russian space programme," said David Redden, a senlor vice-president of Sotheby's and the organizer of the sale.

Nonetheless, profits from the sale will certainly be welcomed by those surviving on state pensions devalued by inflation.

\section{IMAGE UNAVAILABLE FOR COPYRIGHT REASONS}

The widow of Yuri Gagarin, the first man in space, made one space enthusiast very happy when she put the orange space suit he used to train for his historic flight (above, background) up for sale.

Dlaries detailing the changing fortunes of the Soviet space programme and even the title deeds for two 'buggies' still on the Moon - to be paid for on delivery - all added to the total of $\$ \mathbf{\$ 6} .82$ million fetched by the collection. hospitals located just blocks from each other in the centre of Boston, will attempt to consolidate resources in ways that have yet to be determined.

Their goal is to be able to compete for patients and research physicians against lower-cost community hospital consortia that do not specialize in teaching, research and the highest of high-technology medicine. It is a sensible alternative to allowing the two hospitals to continue an intense rivalry that dates back to the 1800 s.

The merger is seen as a precedent for other leading US research hospitals that will have to form some sort of alliances in order to survive health care reform, regardless of which of the many legislative options eventually is enacted into law.

The MGH has already formed a new governing entity, the Massachusetts General Hospital Corporation, which will include the McLean psychiatric hospital and the Spaulding hospital for rehabilitation.

The corporation will be headed by Samuel O. Thier, currently president of Brandeis University and past-president of the Institute of Medicine of the US National Academy of Sciences. Thier received much of his own medical training at the MGH

One likely result of the merger will be a gradual reduction in the number of staff at both hospitals, consistent with the current trend in 'downsizing' hospitals across the country. The challenge of course, is to consolidate resources without sacrificing the quality of research and care provided by these and other university research hospitals across the United States.

Barbara J. Culliton 